\title{
Protective Efiects of Morus alba Leaves Extract on Ocular Functions of Pups from Diabetic and Hypercholesterolemic Mother Rats
}

\author{
H.I.H. El-Sayyad ${ }^{1 凶}$, M.A. El-Sherbiny², M.A. Sobh³ ${ }^{3}$ A.M. Abou-El-Naga1, M.A.N. Ibrahim¹, S.A. Mousa ${ }^{4}$ \\ 1. Laboratory of Experimental Embryology, Zoology Department, Faculty of Science, Mansoura University, Egypt \& * \\ El-Kuwait; \\ 2. National Research Center, Department Immunology, AL-Dokki, Egypt; \\ 3. Urology \& Nephrology Center, Research Center, Mansoura University, Egypt; \\ 4. The Pharmaceutical Research Institute, Albany College of Pharmacy and Health Sciences, Rensselaer, NY, USA.
}

Corresponding author: Hassan I.H. El-Sayyad, PhD, Department of Zoology, Faculty of Science, Mansoura University, Egypt. Email: elsayyad@mans.edu.eg

( ) Ivyspring International Publisher. This is an open-access article distributed under the terms of the Creative Commons License (http://creativecommons.org/ licenses/by-nc-nd/3.0/). Reproduction is permitted for personal, noncommercial use, provided that the article is in whole, unmodified, and properly cited.

Received: 2010.09.28; Accepted: 2011.05.18; Published: 2011.06.04

\begin{abstract}
Phytotherapy is frequently considered to be less toxic and free from side effects than synthetic drugs. Hence, the present study was designed to investigate the protective use of crude water extract of Morus alba leaves on ocular functions including cataractogenesis, biochemical diabetic and hypercholesterolemic markers, retinal neurotransmitters and retinopathy of rat pups maternally subjected to either diabetes and/or hypercholesterolemia. Application of crude water extract of Morus alba resulted in amelioration of the alterations of maternal serum glucose, LDL, HDL, total cholesterol and creatine phosphokinase activity as well as retinal neurotransmitters including acetylcholine $(\mathrm{ACE})$, adrenaline $(\mathrm{AD})$, nor-adrenaline (NAD), serotonin (5-HT), histamine (HS), dopamine (DA) and gamma amino butyric acid (GABA). The retina of pups of either diabetic and/or hypercholesterolemia mothers exhibited massive alterations of retinal neurotransmitters. The alterations of retinal neurotransmitters were correlated with the observed pathological alterations of retinal pigmented epithelium, photoreceptor inner segment and ganglion cells and increased incidence of DNA fragmentation and apoptosis cell death. However, protection with Morus alba extract led to amelioration of the pathological alterations of retinal neurons and estimated neurotransmitters. Furthermore, a striking incidence of cataract was detected in pups of either diabetic and/or hypercholesterolemic mothers. Highest cataractogenesis was observed in pups of combined -treated groups. Our data indicate that experimental maternal diabetes alone or in combination with hypercholesterolemia led to alteration in the ocular structures of their pups, with an increasing incidence of cataract and retinopathy, and the effects of the extract might be attributed to the hypoglycaemic, antihypercholesterolemic and anti-oxidative potential of flavonoids, the major components of the plant extract.
\end{abstract}

Key words: Hypercholesterolemia, Diabetes, Morus Alba L, pups, cataract, retina neurotransmitters, TEM.

\section{INTRODUCTION}

Retinopathy is one of the most common complications of diabetes, which affects approximately $5 \%$ of the world's population suffering from the diabetes $(1,2)$. Cataract is considered to be a major complica- tion of diabetes because approximately 38 million worldwide are blind from cataract, and an additional 110 million people have visual impairment $(3,4)$. There is a significant association between both type I 
and II diabetes and cataract in patients $(5,6)$. Although there is no distinctive relationship between lens cholesterol content and cataract (7), the possibility is that sterol composition of the lens was changed in cataract due to oxidation (8). Neurotransmitters play a key role in the neuro-sensory function of both CNS and retina (9). Histamine acts as a neuro-modulator in retinal blood vessels and inner and outer rod segments (10) and in horizontal cells of guinea pig retina (11). Retinal synchronized activity GABA (12) and glutamate are affected by diabetic retinopathy (13). Retinal pigment epithelium (14) is considered essential in regulation of the glutamate homeostasis. Hypercholesterolemia and diabetes mellitus are accompanied by a wide array of metabolic disorders. Diabetes has been found to be associated with marked changes in vascular histamine levels (15) and acetylcholine metabolism (16). Traditional plant medicines have been used around the world for a range of diabetic presentations; hence the investigations of such medicines are important. Morus alba (Mulberry tree) of the family Moraceae is widely cultivated in countries from temperate to tropical areas. Different parts of the plant are utilized in herbal medicine for blood serum glucose reduction (17) and for cholesterol and lipid level reduction (18).

To date there has not been a study to assess the role retinal neurotransmitters play in congenital ocular disease under the stress of diabetes and hypercholesterolemia during pregnancy. Hence, this investigation was conducted to examine the potential protective effects of Morus alba leaves water extract on ocular functions of pups of diabetic and hypercholesterolemic mother rats.

\section{MATERIAL \& METHODS}

All experiments were conducted in accordance with the national laws for the use of animals in research and approved by the local ethical committee at Al-Mansoura University.

Ninety-six fertile male and virgin female rats (at a ratio of 1 male: 3 females) weighing approximately $125 \mathrm{~g}$ body weight, were obtained from Hellwan Breeding Farm, Ministry of Health, Egypt. Free access of standard diet contained $8.0 \%$ moisture, $20.8 \%$ crude protein, $4.8 \%$ crude fat, $3.2 \%$ crude fiber, $5.0 \%$ crude ash, $37.2 \%$ non-fiber carbohydrate as well as vitamins and minerals adequate to meet the nutritional needs of rat. Free excess of water was allowed ad-libitum. They were housed with good ventilation with a $12 \mathrm{~h}$ light and dark cycle. Females were mated in a special cage ( 1 male/ 3 females) overnight and gestation was determined the next morning by the presence of sperm in a native vaginal smear. The day of concep- tion was considered to be the first day of pregnancy. Vaginal smears were carried out to give a precise determination of the zero day of gestation. Pregnant rats were arranged into 8 groups $(\mathrm{n}=9$ per each) as follows: G0, control; G1, Morus alba-treatment; G2, experimental hypercholesterolemic; G3, experimental hypercholesterolemia + Morus alba-treatment; G4, experimental diabetic; G5, diabetic + Morus alba-treatment; G6, hypercholesterolemic and diabetic; G7, hypercholesterolemic and diabetic + Morus alba.

\section{Crude water extraction of Morus alba leaf}

Four g dried Morus alba leaves were powdered and extracted with $50 \mathrm{x}(\mathrm{w} / \mathrm{v})$ of hot water $\left(85^{\circ} \mathrm{C}\right)$ for 3 h. The extract was filtered with Whatman No. 1 filter paper and concentrated to a volume of $1 / 20$ of the initial solution volume by heating at a non-boiling temperature near $100^{\circ} \mathrm{C}$, and then dried completely under vacuum at $25^{\circ} \mathrm{C}$. The dried extract $(\mathrm{w} / \mathrm{w}=0.59$ $\mathrm{g}$, yield $=15 \%$ ) was used during experimentation and administered at dose of $100 \mathrm{mg} / \mathrm{kg}$ body weight.

\section{Induction of diabetes}

Rats of the normal control group were fed on standard diet free from excess fats and free excess of food and water were allowed ad libitum throughout the experimental period. Experimental diabetes mellitus was induced in all the rats by a single interperitoneal injection of streptozotocin $(60 \mathrm{mg} / \mathrm{kg})$ in citrate buffer $(0.05 \mathrm{M}, \mathrm{pH} 4.5)$ at $5^{\text {th }}$ day of gestation for 2 consecutive days and injected within $10 \mathrm{~min}$ of dissolution (19). Control animals were treated with physiological saline as vehicle. Hyperglycemia was verified by measuring the blood glucose level. A level of more than $300 \mathrm{mg} / \mathrm{dl}$ was selected for this study.

\section{Induction of hypercholesterolemia}

Rats of the normal control group were fed on standard diet free from excess fats and free excess of food and water were allowed ad libitum throughout the experimental period. The experimental group was fed on hypercholesterolemic diet according to Enkhmaa et al. (20). The hypercholesterolemic diet consisted of $3 \%$ cholesterol , $2 \%$ thiouracil, 3\% cholic acid, and 15\% cocoa butter. The diet contained $8.0 \%$ moisture, $20.8 \%$ crude protein, $4.8 \%$ crude fat, $3.2 \%$ crude fiber, $5.0 \%$ crude ash, $37.2 \%$ non-fiber carbohydrate and vitamins and minerals adequate to meet the nutritional needs of a rat. The other experimental groups were fed the same atherogenic diet supplemented with or without Morus alba leave water extract treatment. The diets were continued for 6 weeks prior to onset of gestation. The Morus alba leaves crude water extract applications were started one week be- 
fore either inducing diabetes or feeding on the atherogenic diet. Free excess of diet was supplied ad libitum. The control group was supplemented with a standard diet free from atherogenic components. This study and all procedures were approved by the Animal Care and Bioethics of the Egyptian Committee at Al-Mansoura University.

At parturition, the pups (1-day age) of both control and experimental mother groups were separated and sacrificed. Following decapitation, the ocular organ was removed. The ocular organs of 10 specimens were immediately frozen in liquid nitrogen and stored at $-80^{\circ} \mathrm{C}$ until analysis. The other specimens were processed for light and ultra-structural investigations.

\section{Biochemical assessments}

At parturition, overnight food was removed and the pregnant rats were anesthetized by an i.p. injection of sodium pentobarbital solution $(50 \mathrm{mg} / \mathrm{kg}$ body weight). At the time of sacrifice, blood was collected from hearts into tubes containing $1000 \mathrm{mg} / \mathrm{L}$ EDTA and centrifuged immediately at $1000 \times \mathrm{g}$ for $15 \mathrm{~min}$ at $4^{\circ} \mathrm{C}$. Plasma was stored at $-80^{\circ} \mathrm{C}$ before analysis. Additionally, five pregnant mothers were sacrificed and blood was collected in non-heparinized tube and centrifuged at 5,000 $\times \mathrm{g}$ for $15 \mathrm{~min}$ at $4^{\circ} \mathrm{C}$ and serum was collected. Serum levels of total cholesterol (21) (Deeg and Ziegenhorn, 1983), triglycerides (22) and HDL (23) were determined. LDL-cholesterol concentration (LDLc) was calculated from the total cholesterol concentration (Tc) and the HDL-cholesterol concentration (HDLc) and the triglycerides concentration (TG) according to the equation described by Friedwald et al. (24).

\section{Determination of retinal neurotransmitters}

Levels of seven neurotransmitters, ACE, AD, NAD, 5-HT, HS, DA and GABA, were determined. The retina of both control and experimental groups were homogenized with phosphate buffer $\mathrm{pH} 7.4$ (1:9, $\mathrm{w} / \mathrm{v}$ ) and the homogenate was centrifuged at $4^{\circ} \mathrm{C}$ for $5 \mathrm{~min}$ at $14000 \times \mathrm{g}$ and the supernatant separated. Following flurometric procedure, ACE level was determined according to Gilberstadt and Russell (25) using the following equation: Acetylcholine $(\mu \mathrm{M})=$ Optical density of sample-optical density of blank/Slope $(\mu \mathrm{M}) \times \mathrm{n}$, where $\mathrm{n}$ is dilution factor. $\mathrm{AD}$, NAD, 5-HT and DA were determined fluorometrically as described by Schlumpf et al. (26). Histamine concentration was determined according to Shore et al. (27). GABA was determined by enzyme immunoassay (ELISA) using the IBL kit (USA, REF, IB89150) for the quantitative determination of Glutamate in urine, plasma, serum, cell cultures and tissue homogenates.

\section{Light microscopic investigation}

The ocular region of pups of both control and experimental groups were incised immediately after parturition and fixed in $10 \%$ formal saline and processed for histological investigation. The lens was examined, photographed, and the incidence of cataract was determined.

\section{Transmission electron microscopic investigation}

Extra retina specimens from both control and experimental groups were separated and immediately fixed in $2.5 \%$ gluteraldehyde and $2 \%$ paraformaldhyde in $0.1 \mathrm{M}$ cacodylate buffer $(\mathrm{pH}$ 7.4). After rinsing in $0.1 \mathrm{M}$ cacodylate buffer, they were post-fixed in a buffered solution of $1 \%$ osmium tetra oxide at $4^{\circ} \mathrm{C}$ for $1.5 \mathrm{~h}$ and dehydrated in ascending grades of ethyl alcohol and embedded in epoxy-resin. Ultrathin sections were cut with a diamond knife on a LKB microtome and mounted on grids, stained with urinyl acetate and lead citrate and examined with a Jeol Transmission electron microscope.

\section{Single cell gel electrophoresis (Comet assay)}

The Comet assay is a simple and inexpensive method for the detection of different types of DNA damage including single- and double- stranded breaks, DNA adducts, cross-links, and alkaline-labile sites in a low throughput format. For the assay, eye specimens of both control and experimental groups were homogenized in a chilled homogenizer buffer, $\mathrm{pH} 7.5$ containing $75 \mathrm{mM} \mathrm{NaCl}$ and $24 \mathrm{mM} \mathrm{Na} 2$ EDTA to obtain a $10 \%$ tissue solution. A potter-type homogenizer was used and eye samples were kept on ice during and after homogenization. Six $\mu \mathrm{L}$ of eye homogenate were suspended on $0.5 \%$ low-melting agarose and sandwiched between a layer of $0.6 \%$ normal-melting agarose and a top layer of $0.5 \%$ low-melting agarose on fully-frosted slides. The slides were kept on ice during the polymerization of each gel layer. After the solidification of the $0.6 \%$ agarose layer, the slides were immersed in a lysis solution $(1 \%$ sodium surcosinate, $2.5 \mathrm{M} \mathrm{NaCl}, 100 \mathrm{mM} \mathrm{Na} 2$ EDTA, $10 \mathrm{mM}$ Tris- $\mathrm{HCl}, 1 \%$ tritonX-100 and $10 \%$ DMSO) at $4^{\circ} \mathrm{C}$. After $1 \mathrm{~h}$, the slides were placed in electrophoresis buffer $(0.3 \mathrm{M} \mathrm{NaOH}, 1 \mathrm{mM} \mathrm{Na} 2$ EDTA, $\mathrm{pH} 13)$ for $10 \mathrm{~min}$ at $0^{\circ} \mathrm{C}$ to allow DNA to unwind. Electrophoresis was performed for $10 \mathrm{~min}$ at $300 \mathrm{~mA}$ and 1 $\mathrm{V} / \mathrm{cm}$. The slides were neutralized with Tris- $\mathrm{HCl}$ buffer, $\mathrm{pH} 7.5$, and stained with $20 \mu \mathrm{g} / \mathrm{ml}$ ethidium-bromide for $10 \mathrm{~min}$. Each slide was analyzed using the Leitz Orthoplan (Wetzlar, Germany) epifluo- 
rescence microscope. One hundred cells were analyzed on each slide using the Comet assay II automatic digital analysis system (perspective tail length $(\mu \mathrm{m})$ is the distance of DNA migration from the center of the body of the nuclear core and is used to evaluate the extent of DNA damage). The tail moment is defined as the product of the tail length and the fraction of total DNA in the tail (tail moment=tail length $x \%$ of DNA in the tail). Both tail length and tail intensity were measured automatically by image analysis software (28).

\section{DNA Fragmentation Assay}

DNA fragmentation was assayed by a modification of the method of Duke and Sellins (29). Groups of freshly isolated eye specimens were washed twice with ice-cold PBS and suspended in $100 \mathrm{ml}$ of lyses buffer $(10 \mathrm{mM}$ Tris $\mathrm{HCl} / 10 \mathrm{mM}$ EDTA/0.5\% Triton $\mathrm{X}-100, \mathrm{pH}$ 8.0), vortex-mixed, sonicated, and incubated on ice for $20 \mathrm{~min}$. After centrifugation for 20 $\min$ at $4^{\circ} \mathrm{C}(14,000 \times g)$, the supernatant containing fragmented (soluble) DNA was transferred to another tube. Lyses buffer $(100 \mathrm{ml})$ was added to the pellet containing insoluble DNA. Both samples were treated with RNase A $(0.5 \mathrm{mg} / \mathrm{ml})$ for $1 \mathrm{~h}$ at $37^{\circ} \mathrm{C}$ and then with proteinase K (Sigma, $0.4 \mathrm{mg} / \mathrm{ml}$ ) for $1 \mathrm{~h}$ at $37^{\circ} \mathrm{C}$. After adding $20 \mathrm{ml}$ of $5 \mathrm{M} \mathrm{NaCl}$ and $120 \mathrm{ml}$ of isopropanol, the samples were incubated overnight at $220^{\circ} \mathrm{C}$, and the DNA concentrations were determined. Fragmented DNA was calculated as $100 \%$ x soluble DNA/ (soluble + insoluble DNA). The soluble fraction of DNA was determined by electrophoresis on 1.5\% agarose gel and has a ladder-like appearance.

\section{Biochemical assessments of apoptosis}

Caspase 3 and 7 were determined according to ELISA Kit (Uscn Life Science Inc. Wuhan.) in retinal tissues homogenate of pups of the different experimental groups.

\section{Statistical analysis}

Statistical analysis was done using SPSS MANOVA with comparisons of the multi-variables between the control and the other experimental groups and within the same group. Values were determined and significance at $\mathrm{P}<0.05$.

\section{RESULTS}

\section{Biochemical analysis}

Data from Table 1 illustrates the levels of serum glucose, total cholesterol, triglycerides, and HDL, LDL and creatine phosphokinase in diabetic and hypercholesterolemic mother rats at 15 and 19 days of gestation. At parturition, the fasting blood glucose level reached the highest level in either the diabetic mother alone or in combination with hypercholesterolemia (348 \pm 26.82 and $375 \pm 18.45$, respectively). However, the hypercholesterolemic mother had a less-affected glucose level compared with the other treatments reached to $180 \pm 8.35$. Pups from mothers treated with Morus alba leaves extract retained serum glucose levels to approximately near normal levels, 95 $\pm 7.89,143 \pm 7.43$ and $118 \pm 25.18$ respectively in mother's with hypercholesterolemic alone or and with diabetes. The applied treatments increased the levels of total cholesterol, triglycerides, HDL, LDL and creatine phosphokinase. Highest susceptibility was detected in the combined treatment.

\section{Neurotransmitters}

The retina of pups of either diabetic and/or hypercholesterolemic mothers exhibited an insignificant decrease of AD, NAD and 5-HT, compared with a marked increase of HS, DA and GABA. Protection by Morus alba extract alleviated the alterations of retinal neurotransmitters in diseased groups (Table 2).

\section{Incidence and cataract histology}

Pups of either diabetic and/or hypercholesterolemic mothers exhibited a strikingly increased incidence of cataract $>$ diabetes $>$ hypercholesterolemia. Protection with Morus alba leaves extract inhibited the cataractogenesis (Table 3). In pups of G2, postcapsular cataract was observed in the form of hydropic degenerated lenticular fibers forming large cysts filled with amorphous material (Fig. 1, D and E). However, in pups of G4, the cataractogenesis appeared in the foam cells originating from the lens epithelium and invading the nuclear part of the lens, causing lyses of the lens fibers and forming the perspective nuclear cataract (Fig. $1 \mathrm{G}$ and H). On the other hand, Morus alba protected diabetic and hypercholesterolemic groups (G3 and G5) exhibited marked amelioration of lenticular lesions (Fig. 1 I). Pups of G6 exhibited striking lenticular cataract with a characteristic crescent-shaped structure with obvious necrotic deterioration of lenticular fibers (Fig. 1, J and K). However, partial amelioration was detected in protected Morus alba group G7. The lens fibers took fibrillar reticular structures (Fig. 1, L and M).

\section{Light microscopic observations}

Retina of control pups and those maternally protected by administration of Morus alba extract exhibited normal arrangement of retinal cell layers including the layers of nerve fiber, ganglion cell, inner plexiform, nuclear cell and pigmented epithelium. On the other hand, pups of either maternally diabetic and 
or hypercholesterolemic revealed massive degeneration of nerve fiber, ganglion cells and nuclear cells. Both layers of nerve fibers, ganglion cells and inner plexiform attained considerable atrophy in pups of diabetic and hypercholesterolemic mothers. However, protection with Morus alba extract meliorated the dramatic histological alterations but did not reach the normal structural pattern (Fig. $2 \mathrm{~A}-\mathrm{H}$ ).

Table 1: Biochemical changes of glucose, cholesterol, triglycerides, HDL, LDL and CKin hypercholesterolemic alone or in combination with diabetes and protection by Morus alba leaves extract.

\begin{tabular}{lllllll}
\hline & FBG $(\mathrm{mg} / \mathrm{dL})$ & $\mathrm{TCl}(\mathrm{mg} / \mathrm{dL})$ & TG $(\mathrm{mg} / \mathrm{dL})$ & HDL $(\mathrm{mg} / \mathrm{dL})$ & $\mathrm{LDL}(\mathrm{mg} / \mathrm{dL})$ & $\mathrm{CK}(\mathrm{U} / \mathrm{L})$ \\
\hline G0 & $82 \pm 2.8$ & $50 \pm 2.45$ & $40 \pm 4.2$ & $34 \pm 1.5$ & $28 \pm 1.3$ & $248 \pm 12.4$ \\
G1 & $78 \pm 3.2^{*}$ & $59 \pm 3.7^{*}$ & $43 \pm 4.5^{*}$ & $36 \pm 2.5^{*}$ & $34 \pm 3.7^{*}$ & $255 \pm 15.7^{*}$ \\
G2 & $160 \pm 8.4^{* *}$ & $159 \pm 11.5^{* *}$ & $221 \pm 23.7^{*}$ & $41 \pm 2.1^{* *}$ & $48 \pm 2.1^{* *}$ & $1172 \pm 72.6^{* *}$ \\
G3 & $95 \pm 7.9^{*}$ & $73 \pm 4.3^{* *}$ & $89.4 \pm 4.5^{* *}$ & $32 \pm 2.8^{*}$ & $39 \pm 2.7^{* *}$ & $584 \pm 13.9^{* *}$ \\
G4 & $348 \pm 26.9^{* *}$ & $114 \pm 8.3^{* *}$ & $159 \pm 13.7^{* *}$ & $42 \pm 3.2^{* *}$ & $47 \pm 1.4^{* *}$ & $830 \pm 32.6^{* *}$ \\
G5 & $143 \pm 7.4^{* *}$ & $67 \pm 2.9^{* *}$ & $67.3 \pm 3.9^{* *}$ & $37 \pm 2.2^{*}$ & $40 \pm 3.8^{* *}$ & $387 \pm 11.5^{* *}$ \\
G6 & $375 \pm 18.5^{* *}$ & $187 \pm 4.9^{* *}$ & $287 \pm 12.3^{* *}$ & $46 \pm 3.9^{*}$ & $74 \pm 8.7^{* *}$ & $2132 \pm 43.6^{* *}$ \\
G7 & $158 \pm 25.2^{* *}$ & $93 \pm 5.9^{* *}$ & $113 \pm 8.7^{* *}$ & $37 \pm 3.7^{*}$ & $42 \pm 6.5^{* *}$ & $680 \pm 35.8^{* *}$ \\
\hline
\end{tabular}

Abbreviations: FBG, Fasting blood glucose; TCl, cholesterol; TG, Triglycerides; HDL, High density lipoprotein; LDL, Light density lipoprotein; CK, Creatine phosphokinase. *Non-significant at $\mathrm{P}<0.05$. * Significant at $\mathrm{P}<0.05$.
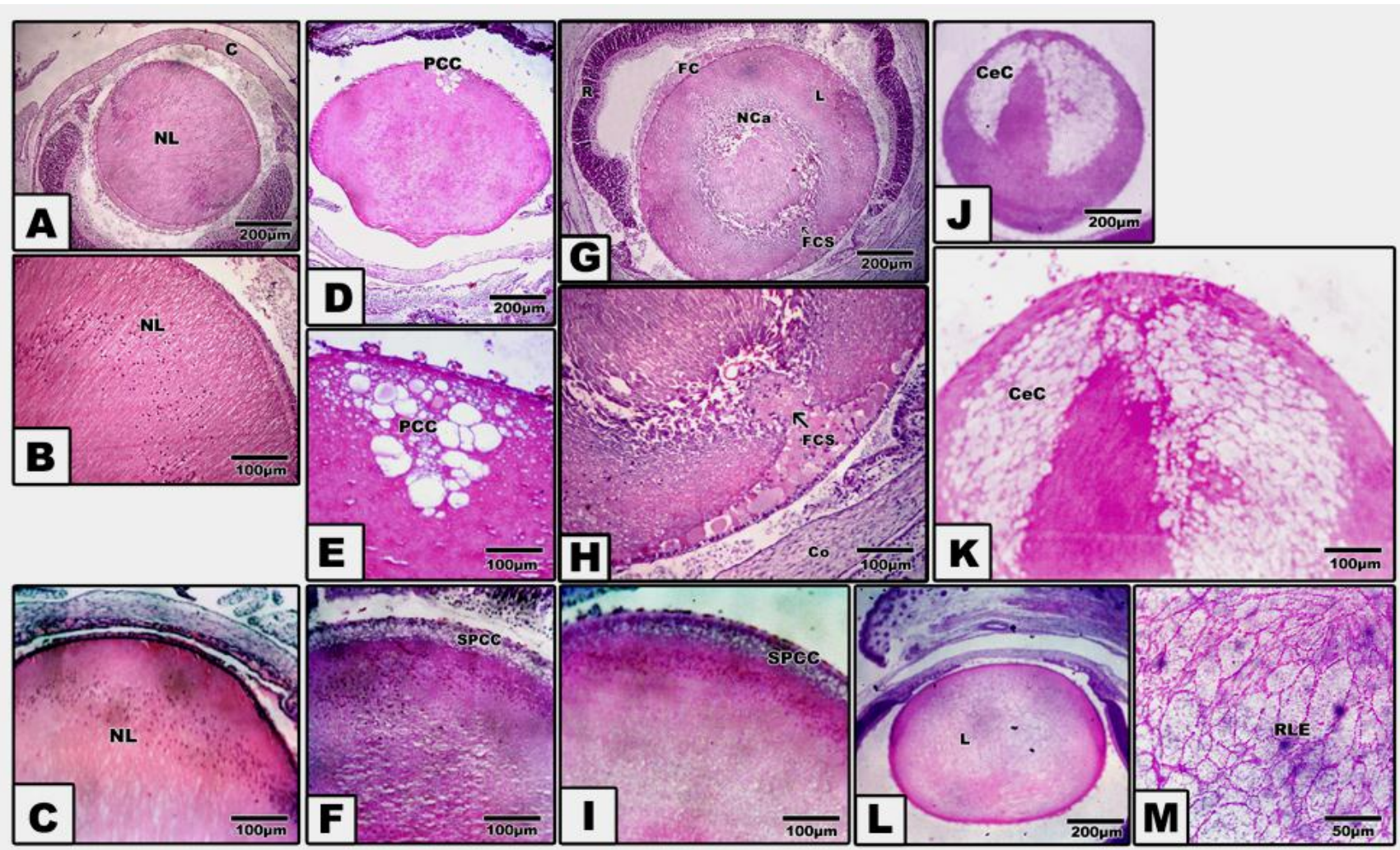

Figure 1. (A to M): Photomicrograph of pups' rat eye lens. A and B: Control showing normal lens fibers. C: Protected Morus alba showing normal pattern-like control. D and E: Maternally diabetic showing postcapsular cataract. F: Maternally diabetic and protected by Morus alba showing amelioration of lens structures. $\mathrm{G}$ and $\mathrm{H}$ : Maternally hypercholesterolemic showing foamy cell infiltration forming nuclear cataract. I: Maternally hypercholesterolemic and protected by Morus alba showing amelioration. J and K: Maternally diabetic and hypercholesterolemic showing neomoon postcapsular cataract. L and M: Maternally diabetic and hypercholesterolemic and protected by Morus alba showing fine reticular structures of lens compared with severe cataract. (Abbreviations: NL, Normal lens; EC, Epithelial cells; Fce, Foam cells; CeC, crescent cataract; NC, Nuclear cataract; PCC, postcapsular cataract; RLF, reticular lens fiber). 

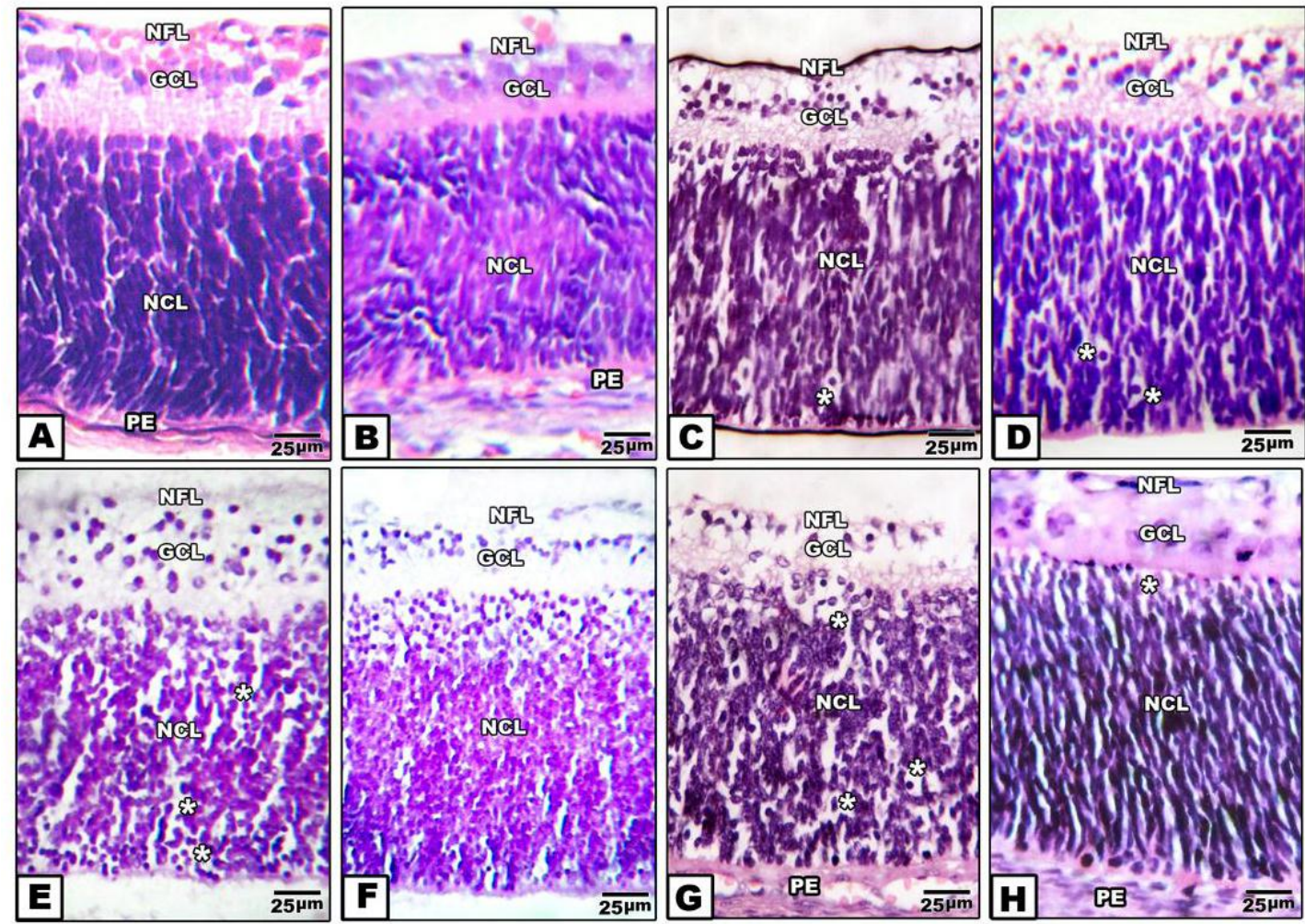

Figure 2 (A to $\mathrm{H})$ : Photomicrographs of transverse histological sections of retina of pups 1 day old of both control and experimental groups. A: Control. B: Maternally protected by Morus alba extract. Both control and protected pups show regular arrangements of retinal cell layers including nerve fiber layer, ganglion cell later, inner plexiform layer, nuclear cell layer and pigmented epithelium. C: Maternally hypercholesterolemic showing degeneration of nerve fiber, gangilion cells and nuclear cells. D: Maternally hypercholesterolemic and protected by Morus alba showing amelioration. E: Maternally diabetic showing degeneration of nerve fiber layer, ganglion cells and nuclear cells. F: Maternally diabetic and protected by Morus alba showing marked amelioration of retinal cell layers. G: Maternally diabetic and hypercholesterolemic showing considerable atrophy of gangilionic \& nerve fiber layer and inner plexiform layer. Many of the nuclear cells are disrupted and degenerated. H: Maternally diabetic and hypercholesterolemic and protected by Morus alba showing amelioration of histological structure. Abbreviations: NFL, Nerve fiber layer; GCL, Ganglion cell layer; NCL, Nuclear cell layer; PE, Pigmented epithelium.

Table 2: Retina neurotransmitters of pups of hypercholestoremic and diabetic mother protected by Morus alba extract.

\begin{tabular}{llllllll}
\hline & $\mathrm{ACE}(\mu \mathrm{M} / \mathrm{g})$ & $\mathrm{AD}(\mathrm{ng} / \mathrm{g})$ & $\mathrm{NAD}(\mathrm{ng} / \mathrm{g})$ & $5-\mathrm{HT}(\mathrm{ng} / \mathrm{g})$ & $\mathrm{HS}(\mathrm{ng} / \mathrm{g})$ & $\mathrm{DA}(\mathrm{ng} / \mathrm{g})$ & $\mathrm{GABA}(\mathrm{ng} / \mathrm{g})$ \\
\hline $\mathrm{G} 0$ & $1.5 \pm 0.2$ & $5.3 \pm 0.2$ & $4.3 \pm 0.1$ & $3.3 \pm 0.1$ & $7.8 \pm 0.1$ & $18.2 \pm 0.1$ & $61.5 \pm 0.2$ \\
G1 & $1.7 \pm 0.2 \#$ & $5.6 \pm 0.1 \#$ & $4.5 \pm 0.2 \#$ & $3.3 \pm 0.2 \#$ & $7.4 \pm 0.1 \#$ & $16.0 \pm 0.2 \#$ & $62.9 \pm 0.2 \#$ \\
G2 & $0.8 \pm 0.2^{*}$ & $5.1 \pm 0.2^{*}$ & $3.8 \pm 0.1^{*}$ & $3.8 \pm 0.1^{*}$ & $9.7 \pm 0.1^{*}$ & $20.4 \pm 0.3^{*}$ & $54.6 \pm 0.3^{*}$ \\
G3 & $1.4 \pm 0.1 \#$ & $5.4 \pm 0.2^{*}$ & $4.6 \pm 0.1 \#$ & $3.2 \pm 0.1 \#$ & $7.3 \pm 0.1 \#$ & $17.6 \pm 0.2 \#$ & $58.0 \pm 0.1 \#$ \\
G4 & $1.1 \pm 0.1^{*}$ & $4.3 \pm 0.2^{*}$ & $4.1 \pm 0.1^{*}$ & $4.0 \pm 0.1^{*}$ & $9.1 \pm 0.1^{*}$ & $24.9 \pm 0.4^{*}$ & $52 . \pm 0.2^{*}$ \\
G5 & $1.2 \pm 0.1^{*}$ & $5.3 \pm 0.6 \#$ & $4.4 \pm 0.1 \#$ & $3.2 \pm 0.1 \#$ & $7.0 \pm 0.1^{*}$ & $21.0 \pm 0.4^{*}$ & $57.9 \pm 0.2^{*}$ \\
G6 & $1.2 \pm 0.1^{*}$ & $4.0 \pm 0.2^{*}$ & $3.7 \pm 0.1^{*}$ & $3.1 \pm 0.1 \#$ & $8.9 \pm 0.1^{*}$ & $26.3 \pm 0.1^{*}$ & $54.1 \pm 0.1^{*}$ \\
G7 & $1.3 \pm 0.4^{*}$ & $5.2 \pm 0.1 \#$ & $4.3 \pm 0.1 \#$ & $3.2 \pm 0.1 \#$ & $6.9 \pm 0.1^{*}$ & $22.1 \pm 0.1^{*}$ & $56.9 \pm 0.4^{*}$ \\
\hline
\end{tabular}

MANOVA application and $\mathrm{F}$ value were determined, *Significant at $\mathrm{P}<0.05$, \# Non-significant at $\mathrm{P}<0.05$. Replicates 5 per each. Abbreviations: G0, control; G1, Morus alba-treatment; G2, Experimental hypercholesterolemic; G3, Experimental hypercholesterolemia + Morus alba-treatment; G4, Experimental diabetic; G5, Diabetic + Morus alba-treatment; G6, Hypercholesterolemic and diabetic; G7, Hypercholesterolemic and diabetic + Morus alba. 
Table 3: Incidence of cataract of rat pups of diabetic and hypercholesterolemic mother protected by Morus alba leaves extract.

\begin{tabular}{lllllllll}
\hline & G0 & G1 & G2 & G3 & G4 & G5 & G6 & G7 \\
\hline Total number of mothers & 10 & 10 & 16 & 12 & 13 & 12 & 15 & 12 \\
Total number of newborn & 87 & 78 & 45 & 67 & 52 & 64 & 43 & 60 \\
Incidence of cataract & $0 \%$ & $0 \%$ & $14(31.11 \%)$ & $1(1.49 \%)$ & $11(21.15 \%)$ & $2(3.13 \%)$ & $17(39.53 \%)$ & $10(16.67 \%)$ \\
Type of cataract & - & - & PCC & MC & NC & VMC & CPCC & RLF \\
\hline
\end{tabular}

Abbreviations: NC, Nuclear cataract; MC, Very mild cataract; PCC, Postcapsular cataract; CPCC, Crescent postcapsular cataract; RLF, Reticulate lenticular fiber.

\section{Retinal pigmented epithelium}

In control and Morus alba-protected mothers, the retinal pigmented epithelium is formed of a single layer of cuboidal cells with Brush's basal membrane adjacent to the choriocapillaries. The cytoplasm is rich in mitochondria and smooth endoplasmic reticulum. The uppermost layer is enclosed by numerous cytoplasm microvilli (Fig. $3 \mathrm{~A}$ and B). In pups of G2, the average numbers of pigmented epithelium were decreased. Their cytoplasm showed abundant distribu- tion of cytoplasmic vacuoles causing distortion of cytoplasmic organelles (Fig. 3 C). In pups of G4, there was a marked increase of pyknotic cell death (Fig. 3 E). On the other hand, in pups of G6, the retinal pigmented epithelium exhibited karyolysis of chromatin material. Cytoplasmic vacuolation and distortion of cytoplasmic organelles were also detected (Fig. 3 G). Protected Morus alba G3, G5 and G7 showed moderate amelioration of cytological structure (Fig. 3 D, F and H).

Figure 3 (G0 to G7): TEM of pups' rat retinal pigmented epithelium. G0: Control. G1: Pups of protected with Morus alba. G2: Maternally diabetic showing pigmented epithelium with vacuolated cytoplasmic structures and pyknotic nuclei and underlying swollen blood coriocapillaries. G3: Maternally diabetic and protected with Morus alba. G4: Maternally hypercholesterolemia showing pyknotic cell death of many pigmented epithelium. G5: Maternally hypercholesterolemic and protected with Morus alba. G6: Maternally diabetic and hypercholesterolemic. G7: Maternally diabetic and hypercholesterolemic and protected by Morus alba. Abbreviations: BV, Blood vessel; IS, inner segment; N. Nucleus; PE, Pigmented epithelium; P, Pyknotic; SBV, Swollen blood vessel.

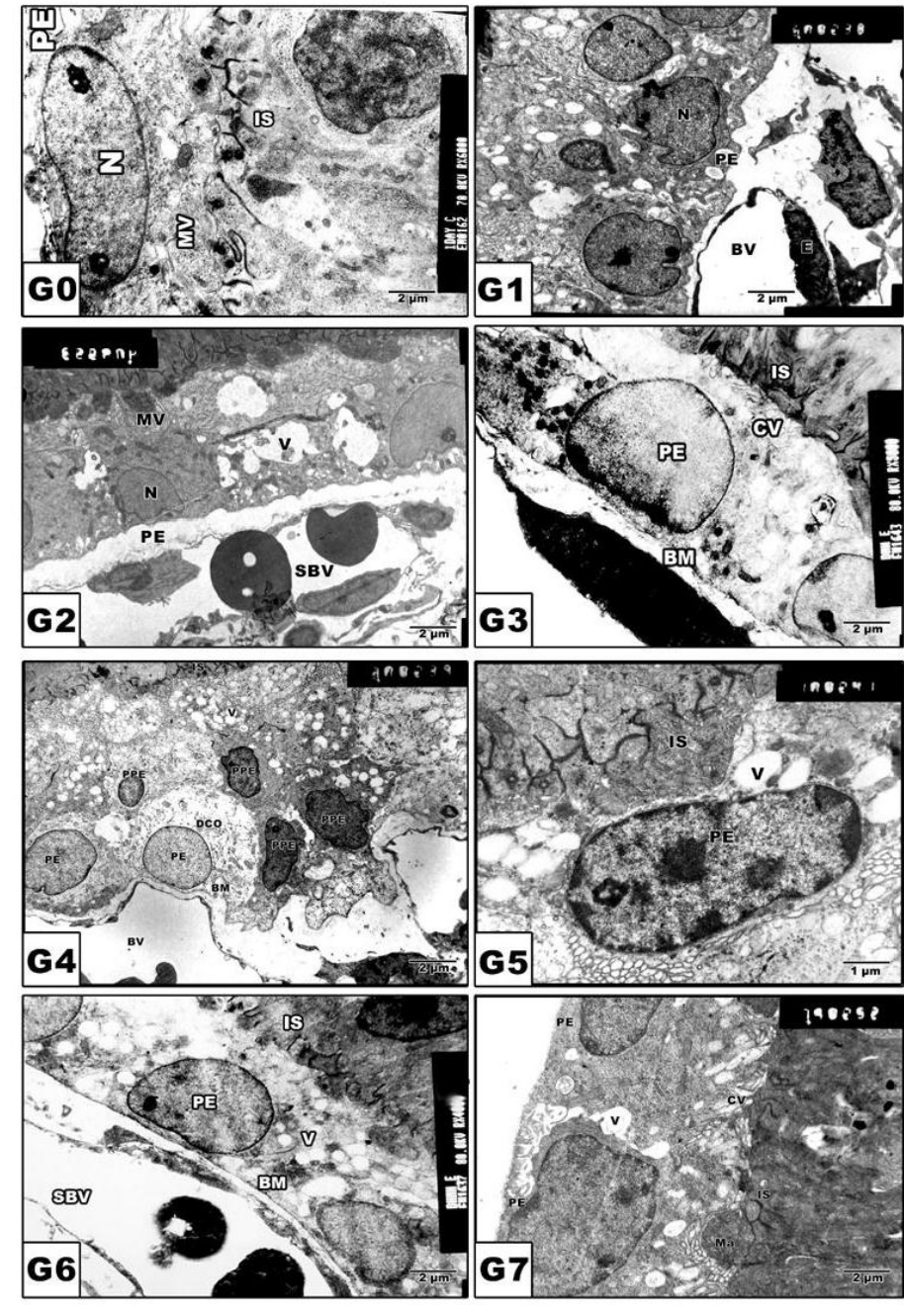




\section{Retinal inner segment}

In pups of G0 and G1, the photoreceptor inner segments are regularly arranged in contact with the pigmented epithelium (Fig. $4 \mathrm{~A}$ and $\mathrm{B}$ ). In pups of experimental groups G2, G4 and G6, there was de- tected abnormal distortion and loss of internal structures (Fig. 4 C, E and G). On the other hand, protected Morus alba G3, G5 and G7 showed ameliorated architecture structure with normal almost intact cytoplasmic structures (Fig. 4 D, F and H).
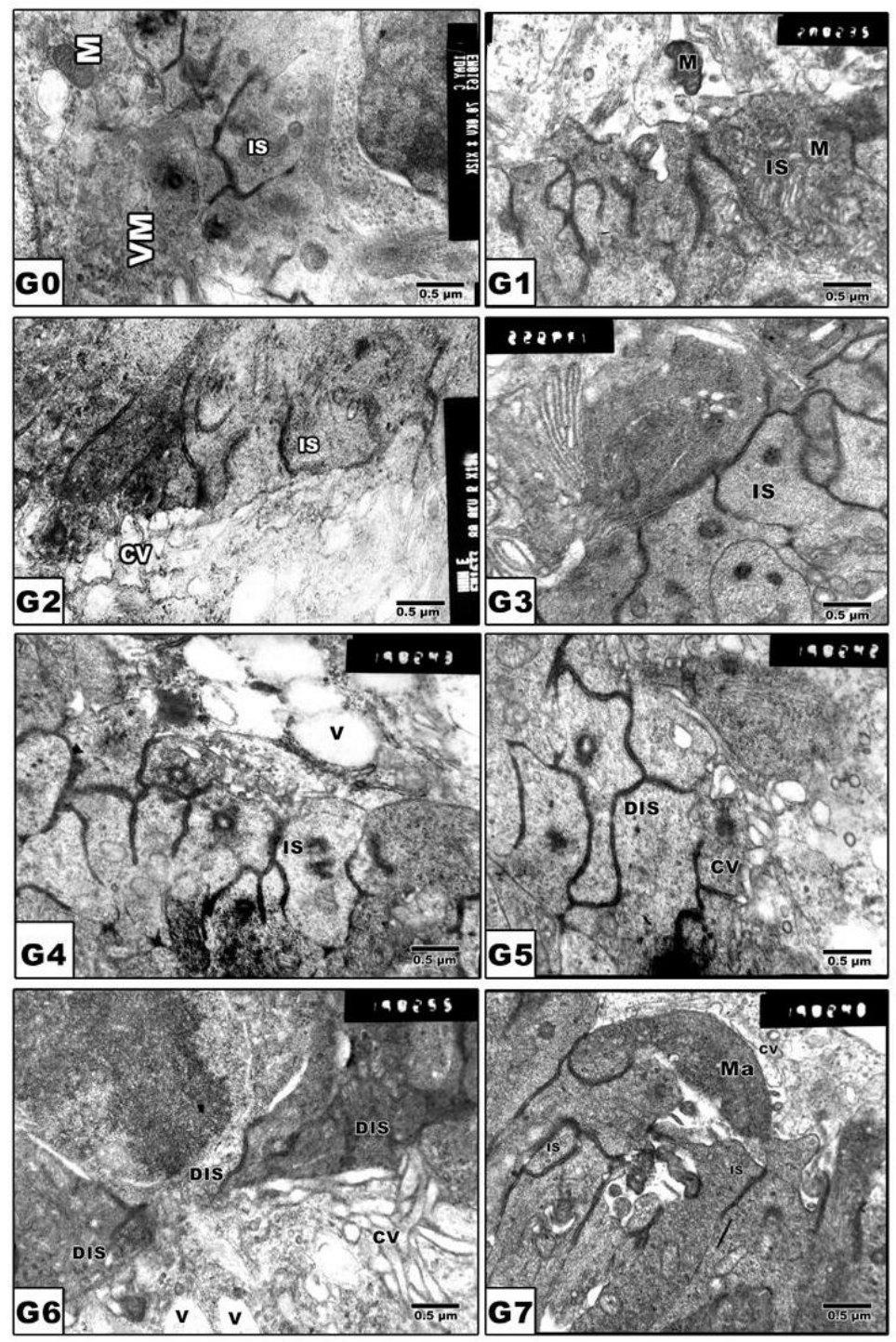

Figure 4 (G0 to G7): TEM of newborn rat retinal inner segment. G0: Control showing regularly-oriented inner segment with characteristic cell organelles. G1: Maternally protected with Morus alba. G2: Maternally diabetic showing disrupted inner segment. G3: Maternally diabetic and protected with Morus alba. G4: Maternally hypercholesterolemic showing disrupted inner segment. G5: Maternally hypercholesterolemic and protected with Morus alba showing nearly normal structure. G6: Maternally diabetic and hypercholesterolemic showing malformed inner segment. G7: Maternally diabetic and hypercholesterolemic and protected by Morus alba showing nearly regularly oriented inner segment but with abundant macrophages adjacent to pigment cell structures. Abbreviations: IS, Inner segment; MIS, Malformed inner segment; Ma, macrophage; V, vacuole; MV, Microvilli. 


\section{Retinal ganglion cells}

In pups of G0 and G1, the ganglion cell bodies vary in size with cytoplasm rich in cytoplasmic organelles (Fig. 5 A and B). On the other hand, pups of G2, G4 and G6 revealed a marked increase of pyknosis and vacuolation of nerve fiber layer (Fig. 5 C, E and G). However, in pups of protected groups G3, G5 and G7, amelioration of cytological structures was detected (Fig. 5 D, F and H).
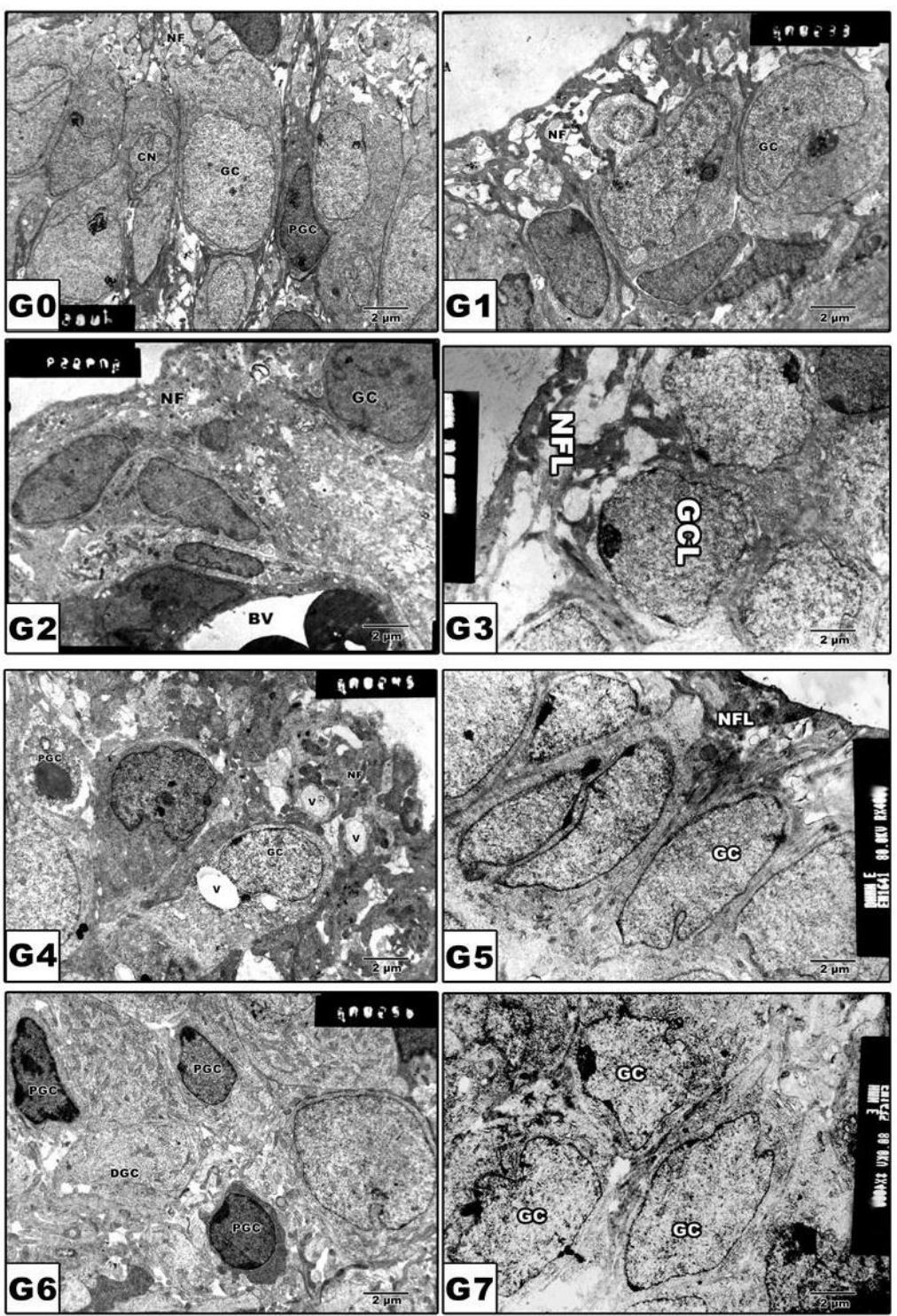

Figure 5 (G0 to G7): TEM of newborn rat retinal ganglion cells. G0: Control showing grouping ganglion cells. G1: Maternally protected with Morus alba showing normal pattern structure. G2: Maternally diabetic showing ganglion cells having pyknotic nuclei. G3: Maternally diabetic and protected with Morus alba. G4: Maternally hypercholesterolemic showing pyknosis of ganglion cells and vacuolation of nerve fibers. G5: Maternally hypercholesterolemic and protected with Morus alba showing ameliorating ganglion cells and nerve fiber layer. G6: Maternally diabetic and hypercholesterolemic showing pyknotic cell death of ganglion cells and vacuolation of nerve fiber. G7: Maternally diabetic and hypercholesterolemic and protected by Morus alba $\mathrm{L}$ showing ameliorated ganglion cells and nerve fibers. Abbreviations: GCL, ganglion cell layer; NFL, Nerve fiber layer. 


\section{Comet Assay}

Following application of the Comet assay, the incidence of apoptosis increased in G2, G4 and G6. Protected Morus alba experimental groups G3, G5 and G7 revealed a reduction of apoptosis as measured by tail length and DNA concentration (Figs. 6 and 7).

\section{DNA damage}

Comparing lanes in Figure 8, DNA damage was detected in pups of G2, G4 and G6 compared with control and protected diseased groups G3, G5 and G7.
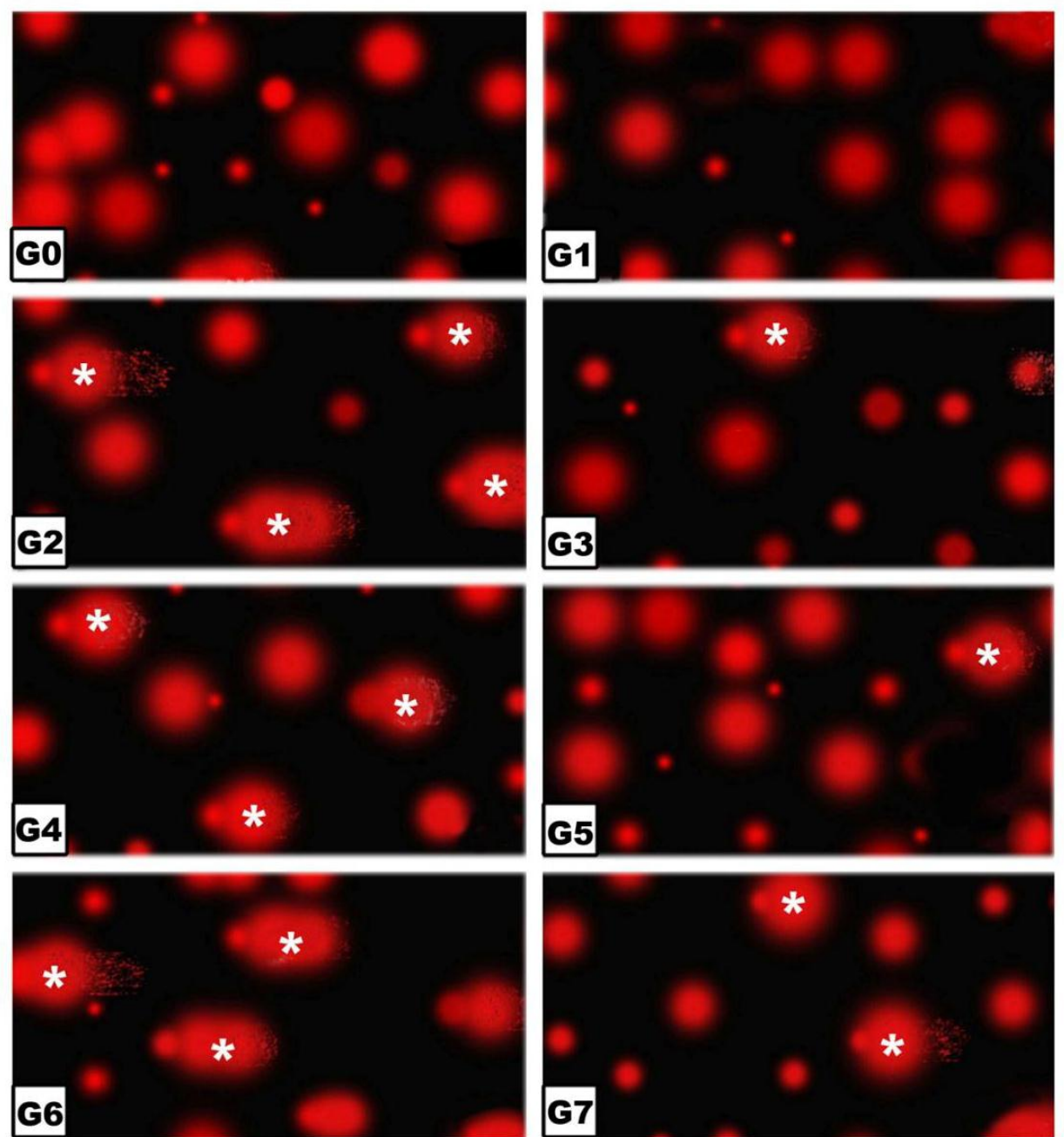

Figure 6 (G0 to G7): Photographs of retina cells of rat pups analyzed by Comet assay analysis. The "dark/red" round spot represents the intact DNA without migration. The less dark "comet-shaped" area adjacent to the nucleus represents DNA breaks that are small enough to move in the gel. Abbreviations: G0: Control. G1: Morus alba. G2: Maternally diabetic. G3: Maternally diabetic and protected with Morus alba. G4: Maternally hypercholesterolemic. G5: Maternally hypercholesterolemic and protected with Morus alba. G6: Maternally diabetic and hypercholesterolemic. G7: Maternally diabetic and hypercholesterolemic and protected by Morus alba. * Means apoptotic cell death. 


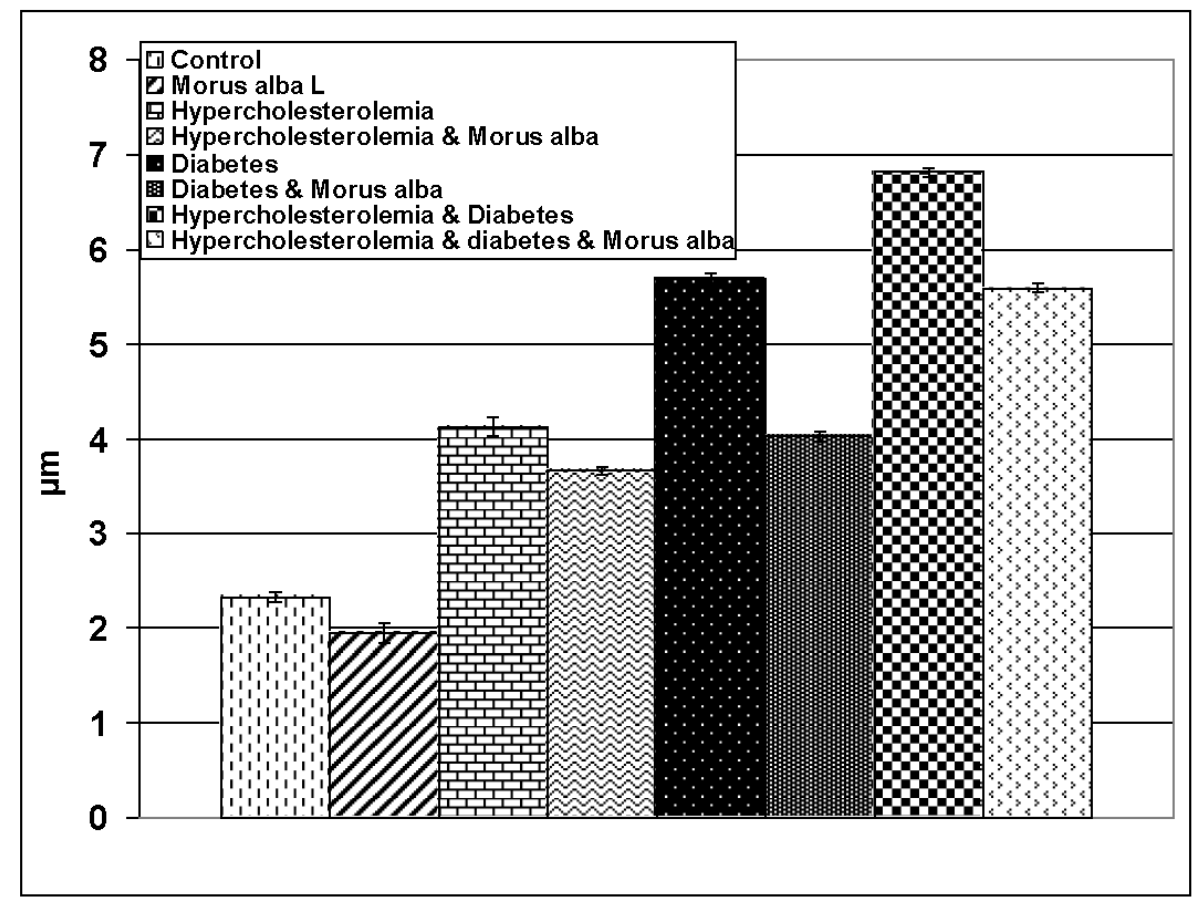

A. Tail length

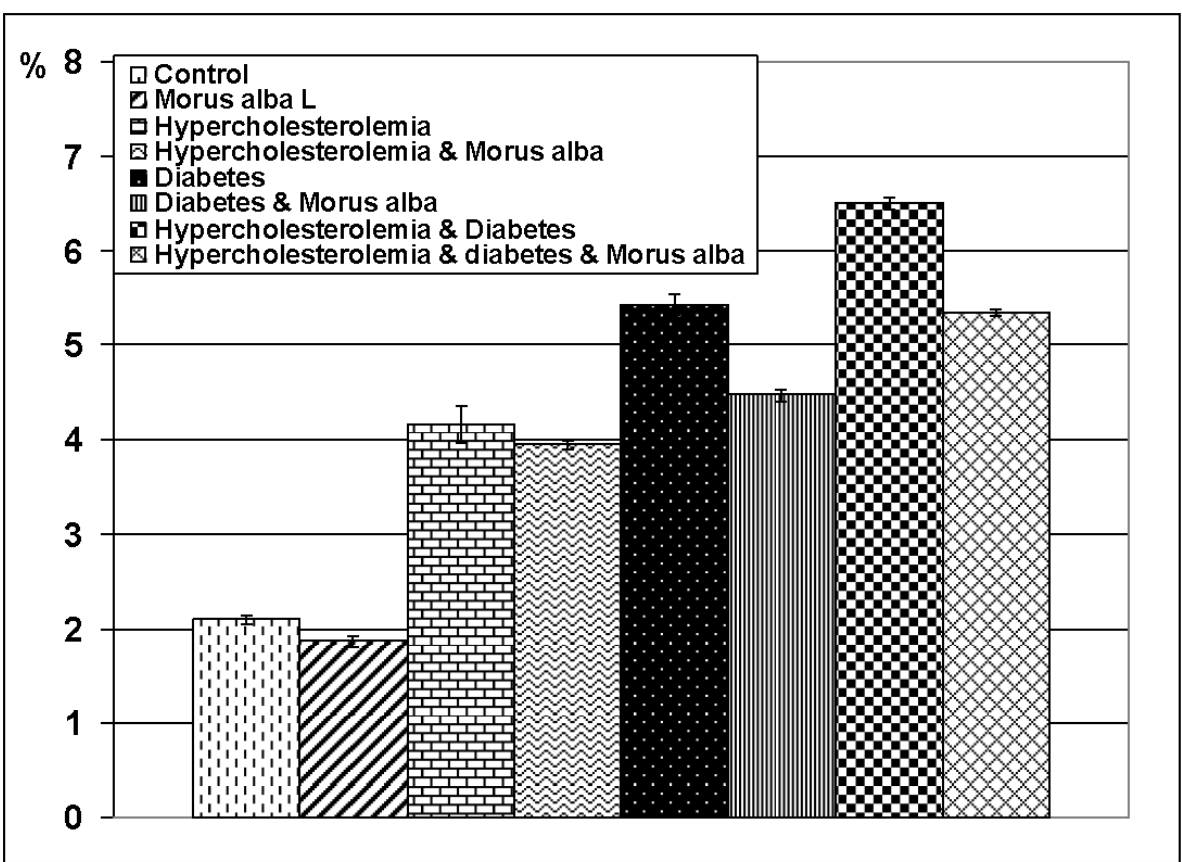

B. DNA concentration

Figure 7 (A and B): Tail length $(\mu \mathrm{m})$ and DNA concentration of pups' retinal neuronal cells maternally subjected to either experimental diabetes and or hypercholesteremia and protected by Morus alba extract. Except hypercholesterolemia and Morus alba, the other groups are significant at $\mathrm{P}<0.05$. 


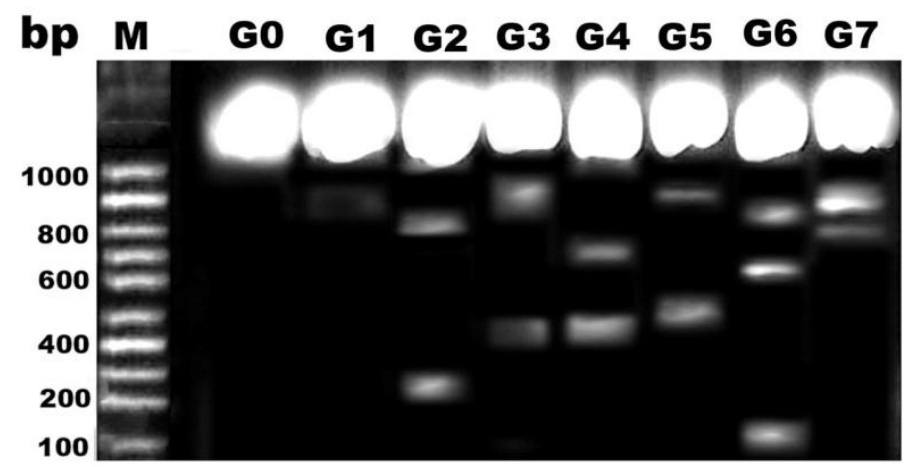

Figure 8: DNA fragmentation of retina of rat pups. Control (G0), Morus alba (G1), hypercholesterolemic (G2), combined hypercholesterolemic and Morus alba (G3), diabetic (G4), combined diabetic and Morus alba (G5), Combined hypercholesterolemic and diabetic (G6) and Combined hypercholesterolemic and diabetic + Morus alba (G7). Hypercholesterolemic alone or combined with diabetes exhibited increased incidence of DNA fragmentation, which was markedly decreased in experimental groups protected by Morus alba extract.

Table 4: Caspase 3 and 7 in rat pups' retinal tissues of diabetic and hypercholesterolemic mother protected by Morus alba leaves extract.

\begin{tabular}{lllllllll}
\hline & C & M & D & DM & H & HM & DH & DHM \\
\hline Caspase 3 (ng/100mg) & $0.38 \pm 0.05$ & $0.37 \pm 0.07$ & $0.58 \pm 0.06$ & $0.38 \pm 0.07$ & $0.57 \pm 0.03$ & $0.39 \pm 0.05$ & $0.59 \pm 0.09$ & $0.39 \pm 0.04$ \\
Caspase 7 (ng/100mg) & $3.44 \pm 0.4$ & $3.51 \pm 0.3$ & $4.1 \pm 0.2$ & $3.76 \pm 0.3$ & $3.93 \pm 0.3$ & $3.55 \pm 0.4$ & $4.25 \pm 0.3$ & $3.483 \pm 0.2$ \\
\hline
\end{tabular}

Each data result represents the Mean $\pm S E$, non-significant at $\mathrm{P}<0.05$. *: significant at $\mathrm{P}<0.05$.

\section{DISCUSSION}

The present findings revealed that experimental diabetes alone or in combination with hypercholesterolemia increased the incidence of congenital cataract being detected in the order of combined treatment $>$ diabetes $>$ hypercholesterolemia. Protection with Morus alba resulted in dramatic alterations in the experimental groups. In congenital diabetes alone or in combination with hypercholesterolemia, cataract formation varied markedly from that of congenital hypercholesterolemia alone. This might be a result of diabetic oxidative stress causing necrosis of lenticular lens fibers, forming large cysts filled with amorphous material. However, congenital hypercholesterolemic cataract seemed to originate from proliferated foam cells that invade the nucleus of the lens, causing lenticular necrosis and development of nuclear cataract. Lens opacity has been detected in diabetic patients $(6$, 32) and in animal models of diabetes that exhibit intracellular accumulation of sugar alcohol and morphological changes including swelling, rounding of nuclei and vacuole formation in peripheral lens epithelial cells of cataract lenses (33). Giavini and Prati (34) reported a case of congenital diabetic cataract in rat fetuses and pups of streptozotocin-diabetic moth- ers. The authors attributed the development of cataract to the disturbance of osmosis in the lens fibers, probably related with an accumulation of some polyols. Depletion of serotonin in experimental diabetes and hypercholesterolemia may cause transient cataracts, probably by decreasing the production of aqueous materials (35). Vinson (36) reported that the opacity of the lens may be related to oxidative stress and generation of superoxide as a result of diabetes.

In the mammalian retina, the release of ACE (37) can affect the response properties of both retinal ganglion cells (38) and retinal pigmented epithelial cells (39) and is implicated in regulating local and global changes in the structural maturation of the retina. In mice lacking ACE, retinal ganglion cells' dendritic stratification was markedly delayed (40). Both diabetes (41) and hypercholesterolemia (42) were found to induce oxidative stress in retinal tissues, causing an insufficient supply of nutrients to the respective target structures (optic nerve, head, retina) and raising glutamate levels, which initiate the retinal neuronal cell death.

The pups of the experimental diseased groups possessed a marked increase of retinal HS and GABA coinciding with degeneration of the ganglion cells and nerve fiber layer. Similar achievements of increased 
GABA (43) and histamine secretion (44) have been reported in diabetic retina. The alteration of DA and catecholamine may share in contributing to the stiffness of retinal arteries enhancing retinal ischemia (45) as detected in arterial thrombosis in atherosclerotic patient (46). Impairment of DA secretion and loss of pigmented epithelium (47) and ganglion cell layer may explain visual deficits in diabetes (48).

In addition, there is a unique relationship between the development and differentiation of retinal pigmented epithelium and photoreceptors (49) manifested by secretion of factors that promote photoreceptor survival and differentiation (50). Consequent$l y$, the increased incidence of apoptotic cell death of retinal pigmented epithelium in pups of experimental diseased groups may in turn disrupt structural components of photoreceptor inner segment.

The present findings show an increased incidence of retinal cell death and DNA fragmentation, which are correlated with alteration of retinal neurotransmitters and neuronal cell damage. Both caspase 3 and 7 attained a marked increase in pups retinal tissues of diabetic and or hypercholesterolemic mothers. This increased incidence of apoptosis confirmed the oxidative stress of maternal diabetes and or hypercholesterolemia in growth of their pups' retinal tissues. Similar increased incidence of apoptotic cells in the streptozotocin diabetic rat retina was detected (51).

On the other hand, a striking amelioration with protected Morus alba extract in experimental diseased groups was shown by attenuating retinal cell death. This may be attributed to the observed hypoglycaemic effects and reduction of LDL, total cholesterol and creatine phosphokinase activity, which have roles in retinal cell damage. Similar attenuation of atherosclerotic lesion development in mice was carried out by quercetin 3-(6-malonylglucoside), the major flavonoids glycoside in mulberry leaves (20). The Morus alba leaves are rich in flavonoids that act as free radical scavengers (52). Quercetin and other flavonoids were shown to bind to the surface of LDL particles (53), and prevented cell death enhancement. In addition, Morus alba leaves were found to exhibit a potent anti-hypoglycaemic effect in diabetic rats (54).

We concluded that the ameliorating effect of mulberry leaves on retinal neurotransmitters, retinal neuronal cells and anti-cataract activity may be attributed to its flavonoids content, which shows potential anti-oxidative activity and has potential hypoglycaemic and anti-hypercholesterolemic effects.

\section{Conflict of Interests}

The authors have declared that no conflict of interest exists.

\section{References}

1. Mohamed Q, Gillies MC, Wong TY. Management of diabetic retinopathy: a systematic review. JAMA. 2007; 298(8): 902-916.

2. Cheung N, Mitchell P, Wong TY. Diabetic retinopathy. Lancet. 2010; 376(9735): 124-36.

3. Brian $\mathrm{G}$ and Taylor H. Cataract blindness--challenges for the 21st century. Bull World Health Organ. 2001; 9(3): 249-256.

4. Florkowski AR, Golden R, Sooch Y, Krishna R. Sudden bilateral visual loss in a diabetic man. Am J Med Sci. 2005; 329(2): 99-101.

5. Kumamoto Y, Takamura Y, Kubo E, Tsuzuki S and Akagi Y. Epithelial cell density in cataractous lenses of patients with diabetes: Association with erythrocyte aldose reductase. Exp Eye Res. 2007; 85: 393-399.

6. Esteves JF, Dal Pizzol MM, Sccoco CA, Roggia MF, Milano SB, Guarienti JAA, Rodrigues TC and Canani LH. Cataract and type 1 diabetes mellitus. Diab Res \& Clin Practice. 2008; 82: 324 $-328$.

7. Rosenfeld L and Spector A. Changes in lipid distribution in the human lens with the development of cataract. Exp Eye Res. 1981; 33:641-650.

8. Dillon J, Mehlman B, Ponticorvi L, Spector A. The state of neutral lipids in normal and cataractous human lenses. Exp Eye Res. 1983; 37: 91-98.

9. Nowak JZ. The isolated retina as a model of the CNS in pharmacology. Trends Pharmacol Sci. 1988; 9: 80- 82.

10. Nowak JZ; Nawrocki J, and Maslinski C. Distribution and localization of histamine in bovine and rabbit eye. Agents Actions. 1984; 14(3-4): 335-340.

11. Ando-Yamamoto $M$, Kiyama $H$, Hayashi $H$, Fukui $H$, Tohyama M, Watanabe T, Wada H. Demonstration of histaminergic neurons in horizontal cells of guinea pig retina. Brain Res. 1987; 410: 269-274.

12. Sernagor E, Eglen SJ, Wong RO. Development of retinal ganglion cell structure and function. Prog Retin Eye Res. 2001; 20: 139-174.

13. Semkova I, Huemmeke M, Ho MS, Merkl B, Abari E, Paulsson M, Joussen AM, Plomann M. Retinal localization of the glutamate receptor GluR2 and GluR2-regulating proteins in diabetic rats. Exp Eye Res. 2010; 90(2): 244-253.

14. Pow DV. Visualising the activity of the cystine-glutamate antiporter in glial cells using antibodies to aminoadipic acid, a selectively transported substrate. Glia. 2001; 34(1): 27-38.

15. Orlidge A and Hollis TM. Aortic endothelial and smooth muscle histamine metabolism in experimental diabetes. Arteriosclerosis. 1982; 2: 142-150.

16. Okada Y, Yamanaka I, Sakamoto T, Hata Y, Sassa Y, Yoshikawa $\mathrm{H}$, Fujisawa K, Ishibashi T and Inomata H. Increased expression of angiotensin converting enzyme in retinas of diabetic rats. Jpn J Ophthalmol. 2001; 45: 585- 591.

17. Andallu B and Varadacharyulu NCH. Control of hyperglycemia and retardation of cataract by mulberry (Morus indica L.) leaves in streptozotocin diabetic rats. Indian J Exp Biol. 2002; 40(7): 791-795.

18. Chen J and Li X. Hypolipidemic effect of flavonoids from mulberry leaves in triton WR-1339 induced hyperlipidemic mice. Asia Pac J Clin Nutr. 2007; 16(Suppl 1): 290-294.

19. Povoski SP, McCullough PJ, Zhou W, Bell RH. Induction of diabetes mellitus in Syrian Golden Hamsters using stored equilibrium solutions of streptozotocin. Lab An Sci. 1993; 43: 310-313. 
20. Enkhmaa B, Shiwaku K, Katsube T, Kitajima K, Anuurad E, Yamasaki M, and Yamane Y. Mulberry (Morus alba L.) Leaves and Their Major Flavonol Quercetin 3-(6-Malonylglucoside) Attenuate Atherosclerotic Lesion Development in LDL Receptor-Deficient Mice. J. Nutr. 2005; 135: 729-734.

21. Deeg R and Ziegenhorn J. Kinetic enzymic method for automated determination of total cholesterol in serum. Clin Chem. 1983; 29(10): 1798-1802.

22. Fossati P and Prencipe L. Serum triglycerides determined colorimetrically with an enzyme that proceduces hydrogen peroxide. Clin Chem. 1982; 28(10): 2077-2080.

23. Friedewald WT, Levy RI and Fredrickson DS. Estimation of low density lipoprotein cholesterol in plasma without use preparative ultracentrifuge. Clin Chem. 1972; 18(6): 499-502.

24. Grove TH (1979). Effect of reagent PH on determination of the high-density lipoprotein cholesterol by precipitation with sodium phototungestate-magnesium. Clin Chem. 1979; 25(4): 560-564.

25. Gilberstadt ML, Russell JA. Determination of picomole quantities of acetylcholine and choline in physiologic salt solutions. Anal Biochem. 1984; 138: 78-85.

26. Schlumpf M, Lichtensteiger W, Langemann H, Waser PG and Hefti FA. Fluorometric micromethod for the simultaneous determination of serotonin, noradrenaline and dopamine in milli gram amounts of brain tissue. Biochem Pharm. 1973; 23: 2337.

27. Shore PA, Burkhalter A and Cohn VH. A method for the fluorometric assay of histamine in tissues. J Pharmacol Exp Ther. 1959; 127: 182-186.

28. Sasaki YF, Nishidate E, Izumiyama F, Matsusaka N and Tsuda S. Simple detection of chemical mutagen by the alkaline single-cell gel electrophoresis (Comet) assay in double mouse organs (liver, lung, spleen, kidney, and bone marrow). Mutat Res. 1997; 391: 215-231.

29. Duke RC and Sellins CB. In: Kaplan JG, ed. Cellular Basis of Immune Modulation. New York:Liss; 1989: 311-314.

30. West SD, Groves DC, Lipinski HJ, Nicoll DJ, Mason RH, Scanlon PH, Stradling JR. The prevalence of retinopathy in men with Type 2 diabetes and obstructive sleep apnoea. Diabet Med. 2010; 27(4): 423-430.

31. Triviño A, Ramírez AI, Salazar JJ, de Hoz R, Rojas B, Padilla E, Tejerina T, Ramírez JM. A cholesterol-enriched diet induces ultrastructural changes in retinal and macroglial rabbit cells. Exp Eye Res. 2006; 83(2): 357-366.

32. Kumamoto Y, Takamura Y, Kubo E, Tsuzuki S, Akagi Y. Epithelial cell density in cataractous lenses of patients with diabetes: association with erythrocyte aldose reductase. Exp Eye Res. 2007; 85(3): 393-399.

33. Takamura Y, Kubo E., Tsuzuki S, Akagi Y. Apoptotic cell death in the lens epithelium of rat sugar cataract. Exp Eye Res. 2003; 77: 51-57.

34. Giavini E and Prati M. Morphogenesis of Diabetes-Induced Congenital Cataract in the Rat. Acta Anatomica. 1990; 137: 132-136.

35. Boerrigter RM, Siertsema JV, Kema IP. Serotonin (5-HT) and the rat's eye. Some pilot studies. Doc Ophthalmol.1992; 82(1-2): 141-150.

36. Vinson JA. Oxidative stress in cataracts. Pathophysiol. 2006; 13 : 151-162.

37. Masland RH, Mills JW, and Hayden SA. Acetylcholine-synthesizing amacrine cells: identification and selective staining by using radioautography and fluorescent markers. Proc R Soc Lond B Biol Sci. 1984; 223: 79-100.

38. Baldridge WH. Optical recordings of the effects of cholinergic ligands on neurons in the ganglion cell layer of mammalian retina. J Neurosci. 1996; 16: 5060-5072.

39. Sekiguchi-Tonosaki M, Obata M, Haruki A, Himi T, Kosaka J. Acetylcholine induces $\mathrm{Ca} 2+$ signaling in chicken retinal pig- mented epithelial cells during dedifferentiation. Am J Physiol Cell Physiol. 2009; 296(5): C1195-206.

40. Bansal A, Singer JH, Hwang BJ, Xu W, Beaudet A, Feller MB. Mice lacking specific nicotinic acetylcholine receptor subunits exhibit dramatically altered spontaneous activity patterns and reveal a limited role for retinal waves in forming ON and OFF circuits in the inner retina. J Neurosci. 2000; 20: 7672-7681.

41. Bytyqi AH, Lockridge O, Duysen E, Wang Y, Wolfrum U, Layer PG. Impaired formation of the inner retina in an AChE knockout mouse results in degeneration of all photoreceptors. Eur J Neurosci. 2004; 20: 2953-2962.

42. Torres RJA, Maia M, Précoma DB, Noronha L, Luchini A, Précoma LB, Greyce Kelly de Souza GK, and Muccioli C. Evaluation of early abnormalities of the sensory retina in a hypercholesterolemia experimental model: An immunohistochemical study. Arq Bras Oftalmol. 2009; 72(6): 793-798.

43. Ramsey DJ, Ripps H, Qian H. Streptozotocin-induced diabetes modulates GABA receptor activity of rat retinal neurons. Exp Eye Res. 2007; 85(3): 413-22.

44. Carroll WJ, Hollis TM, and Gardnerf TW. Retinal Histamine Synthesis Is Increased in Experimental Diabetes. Invest Ophthalmol Vis Sci. 1988; 29: 1201-1220.

45. Nakazawa T, Sato A, Mori A, Saito M, Sakamoto K, Nakahara $\mathrm{T}$, Ishii K. Beta-adrenoceptor-mediated vasodilation of retinal blood vessels is reduced in streptozotocin-induced diabetic rats. Vascul Pharmacol. 2008; 49(2-3): 77-83.

46. Hayreh SS and Podhajsky P. Ocular neovascularization with retinal vascular occlusion, II: occurrence in central and branch retinal artery occlusion. Arch Ophthalmol. 1982; 100(10): 1585-1596.

47. Kralj-Hans I, Tibber M, Jeffery G, Mobbs P. Differential effect of dopamine on mitosis in early postnatal albino and pigmented rat retinae. J Neurobiol. 2006; 66(1): 47-55.

48. Gastinger MJ, Singh RS, Barber AJ. Loss of cholinergic and dopaminergic amacrine cells in streptozotocin-diabetic rat and Ins2Akita-diabetic mouse retinas. Invest Ophthalmol Vis Sci. 2006; 47(7): 3143-3150.

49. Marmorstein AD. The polarity of the retinal pigment epithelium. Traffic. 2001; 2: 867-872.

50. Adamis AP, Shima DT, Yeo KT, Yeo TK, Brown LF, Berse B, D'Amore PA, and Folkman J. Synthesis and secretion of vascular permeability factor/vascular endothelial growth factor by human retinal pigment epithelial cells. Biochem Biophys Res Commun. 1993; 193: 631-638.

51. Afanasev IB, Dorozhko AI, Brodskii AV, Kostyuk VA. and Potapovitch AI. Chelating and free radical scavenging mechanisms of inhibitory action of rutin and quercetin in lipid peroxidation. Biochem Pharmacol. 1989; 38: 1763-1769.

52. Hayek T, Fuhrman B, Vaya J, Rosenblat M, Belinky P, Coleman R., Elis A and Aviram M. Reduced progression of atherosclerosis in apolipoprotein E-deficient mice following consumption of red wine, or its polyphenols quercetin or catechin, is associated with reduced susceptibility of LDL to oxidation and aggregation. Arterioscler. Thromb Vasc Biol. 1997; 17: 2744-2752.

53. Hu ML. Antioxidant role of mulberry leaves in streptozotocin-diabetic rats. Clinica Chimica Acta. 2004; 348: 215.

54. Mohammadi J and Naik PR. Evaluation of hypoglycemic effect of Morus alba in an animal model. Ind J Pharmacol. 2008; 40(1): 15-18. 